\title{
The Effectiveness of Coriander Seed Extract (Coriandrum Sativum) on Lowering Cholesterol Levels in Elderly Patients with Hypercholesterolemia
}

\author{
Ana Setyowati ${ }^{*}$, Ni'matul Ulya ${ }^{1}$ \\ ${ }^{I}$ Akademi Kebidanan Harapan Ibu Pekalongan, Jl. Sriwijaya No 7 Kota Pekalongan \\ * Corresponding author \\ E-mail:renex_cubby@yahoo.co.id
}

\begin{abstract}
The World Health Organization (WHO) estimates that by 2025 the number of elderly people worldwide will reach 1.2 billion people which will continue to grow up to 2 billion people in 2050. Cholesterol is important for our body, but in fact excessive cholesterol levels in the blood can be harmful to health since that can cause hypertension and blockage of the blood vessels of the brain, heart and leg. Actually, Hypercholesterolemia in the elderly can be reduced by non-pharmacological treatment using coriander seeds. The purpose of this study was to determine how much decreased cholesterol levels in elderly patients with hypercholesterolemia. This research is a quasi-experimental study with coriander seed extract as a treatment. The sampling is using multistage random sampling technique of 15 elderly people per group. The data analysis technique used an independent $\mathrm{T}$ test. The results showed that the significance value of the treatment group and the control group before was 0.063 , while the significance value after treatment was 0.038 . This research can contribute to the community and health workers to seek herbal treatment methode for the elderly with hypercholesterolemia.
\end{abstract}

Keywords: Elderly, Coriander Seed, Hypercholesterolemia

\section{INTRODUCTION}

The World Health Organization (WHO) estimates that by 2025 the number of elderly people worldwide will reach 1.2 billion people which will continue to grow up to 2 billion people in 2050. Cholesterol is a fatty substance circulating in the blood, yellowish in color and shaped like a wax, which is produced by the liver and is needed by the body which functions to make sex hormones, adrenals, and forms cell walls. Cholesterol is important for the body nevertheless excessive cholesterol levels in the blood can be harmful to health ${ }^{[1]}$.
Many physiological changes occur in the elderly. These changes are not pathological, but can make the elderly more susceptible to several diseases. Diseases that may appear in the elderly are as a result of the degenerative process (aging) so that noncommunicable diseases often appear in the elderly. Non-communicable diseases in the elderly include cholesterol, hypertension, gout, stroke, diabetes mellitus and arthritis or rheumatism ${ }^{[2]}$.

In addition to medical treatment, traditional medicine can also be done to lower high cholesterol levels. Traditional medicine is proven to be naturally safe and 
useful and can be combined as complementary or alternative medicine if conventional therapy cannot be given ${ }^{[3]}$.

As an alternative nonpharmacological treatment, coriander seed extract can be used as an effort to reduce the high cholesterol levels in patients with hypercholesterolemia. The results of phytochemical screening of coriander seed extract showed the presence of flavonoid compounds, alkaloids, saponins, tannins, phenolics, triterpenoids, and glycosides ${ }^{[4]}$.

The content of flavonoids plays an important role in lowering cholesterol level and as an antioxidant. Vitamin $\mathrm{C}$ and Vitamin B can be found in Coriander seeds. As we know, Vitamin $\mathrm{C}$ acts as an antioxidant therefore it plays an essential role in preventing and reducing the dangers posed by free radicals. Free radicals are compounds that can interfere with the body's metabolism that are harmful to health ${ }^{[5]}$.

The purpose of this study was to determine how much the decrease in cholesterol levels in the elderly with hypercholesterolemia. This research can contribute in the field of health sciences by using herbal therapy in the form of coriander seed extract in lowering cholesterol levels in the elderly with hypercholesterolemia.

\section{METHOD}

This research uses an experiment (experimental design). The design of this study used a quasi-experimental research design with a non-equivalent control group design approach. In this study, two groups were used, namely the treatment group and the control group. The treatment group was given an intervention in the form of coriander seed extract for 14 days which was recorded on the observation sheet while the control group was given health education about healthy eating patterns and lifestyles.

This research was conducted at Pekalongan City Health Centers, namely Tirto, Tondano, Dukuh and Jenggot Public Health Centers The research sample was taken using multistage random sampling technique. The number of samples taken for this study was 15 people per group according to Roscue's (1975) theory, namely the number of samples for simple experimental research was set at 10-20 samples ${ }^{[6]}$. The method of data collection was carried out using the Cholesterol Check Tool instrument, and observation sheets.

The data analysis technique used is univariate analysis and bivariate analysis using independent T-test. The guideline in accepting the hypothesis is that if the $\mathrm{P}$ value $<0.05$ then Ho is rejected and Ha states that there is an effect. This research has also received ethical approval by the Research Ethics Commission of Sultan Agung Islamic University Semarang under certificate Number: 134/IV/2021/Komisi Bioetik.

\section{RESULT \\ A. Respondent Characteristics}

Table 1. Characteristics of respondents by age and gender

\begin{tabular}{lcc}
\hline Variable & \multicolumn{2}{c}{ Group } \\
& Treatment & $\begin{array}{c}\text { Control } \\
(\mathbf{n = 1 5})\end{array}$ \\
\hline Age (Years) & & \\
Mean \pm SD & $67,60 \pm 5,865$ & $68,27 \pm 5,405$ \\
Median & 67 & 67 \\
Min \pm Max & $60 \pm 78$ & $65 \pm 79$ \\
Gender & & \\
Male & $4(26,7 \%)$ & $7(46,7 \%)$ \\
Female & $11(73,3 \%)$ & $8(53,3 \%)$ \\
\hline Source: Primary data, 2021 &
\end{tabular}

Based on the table above, we get characteristics of respondents based on age obtained results in the treatment group mean 67.60 years, median 67 years, minimum 60 years and maximum 78 years with a standard deviation of 5.865. In the control group, the results obtained mean 68.27 years, median 67 years, minimum 65 years and maximum 79 years with a standard deviation of 5.405 .

Characteristics of respondents based on gender showed that in the treatment group there were 11 respondents $(73.3 \%)$ with female sex and 4 respondents $(26.7 \%)$ male. While in the control group there were 8 female respondents $(53.3 \%)$ and 7 male respondents $(46.7 \%)$. 


\section{B. Independent T-test result}

Table 2. The Effect of Coriander Seed Extract on Reducing Cholesterol Levels in Hypercholesterolemic Elderly

\begin{tabular}{lccc}
\hline \multicolumn{1}{c}{$\begin{array}{c}\text { Level of } \\
\text { Cholesterol }\end{array}$} & \multicolumn{2}{c}{ Mean \pm SD; Median; Min \pm Max } \\
Treatment $(\mathbf{n}=15)$ & Control $(\mathbf{n}=\mathbf{1 5})$ & P-Value $^{\boldsymbol{a}^{\boldsymbol{a}}}$ \\
\hline Before & $264,93 \pm 41,685 ; 254 ; 213 \pm 343$ & $231,73 \pm 19,006 ; 187 ; 212 \pm 276$ & 0,063 \\
After & $192,73 \pm 40,195 ; 187 ; 121 \pm 266$ & $216,80 \pm 21,641 ; 223 ; 180 \pm 249$ & 0,038 \\
\hline
\end{tabular}

Based on table 2 above, it can be seen that the average cholesterol level in the treatment group before consuming coriander seed extract was $264.93 \mathrm{mg} / \mathrm{dl}$ with the lowest cholesterol level of $213 \mathrm{mg} / \mathrm{dl}$ and the highest cholesterol level of $343 \mathrm{mg} / \mathrm{dl}$. Meanwhile, the average cholesterol level after consuming coriander extract (14 days later) was $192.73 \mathrm{mg} / \mathrm{dl}$ with the lowest cholesterol level being $121 \mathrm{mg} / \mathrm{dl}$ and the highest cholesterol level being $266 \mathrm{mg} / \mathrm{dl}$.

While in the control group the average cholesterol level was $231.73 \mathrm{mg} / \mathrm{dl}$ with the lowest cholesterol level being 212 $\mathrm{mg} / \mathrm{dl}$ and the highest cholesterol level being $276 \mathrm{mg} / \mathrm{dl}$. While the average cholesterol level on day 14 of the control group was $216.80 \mathrm{mg} / \mathrm{dl}$ with the lowest cholesterol level being $180 \mathrm{mg} / \mathrm{dl}$ and the highest cholesterol level being $249 \mathrm{mg} / \mathrm{dl}$.

Based on the results of the independent $t$ test, the significance value in the treatment group and the control group before being given coriander seed extract was 0.063 ( $\mathrm{p}$ value > 0.05), which means there was no difference in cholesterol levels between the treatment group and the control group. Meanwhile, the significance value in the treatment group and the control group after treatment was 0.038 ( $\mathrm{p}$ value <0.05), which means that there was a difference in cholesterol levels between the treatment group and the control group.

\section{DISCUSSION}

From the results obtained that the average age of the elderly affected by hypercholesterolemia in the treatment group was 67.60 years and 68.27 years in the control group. According to the results of Suherwin's research (2018), it was stated that the greater the age, the greater the risk of coronary heart disease. Due to the increasing age, the function of the body's organs will decrease due to aging ${ }^{[7]}$.

Metabolic rate in the elderly decreased by about 15 to $20 \%$, due to reduced mass muscle. Scientific facts say that muscles use more energy than fat, so fat becomes more buried in the body (Zuhroiyyah et al, 2017). If usage energy decreases, then the food that should be formed into energy will converted to cholesterol ${ }^{[8]}$.

Increasing age also increases the risk of coronary heart attack significantly in both, men and women. This is due to unhealthy lifestyles such as lack of exercise, eating unhealthy foods that contain lots of cholesterol, and unhealthy lifestyles. This is in accordance with the results of the Mintalangi study (2013) that an older age will have relatively higher cholesterol levels than cholesterol levels at a young age ${ }^{[9]}$.

For gender, the results in the treatment group were 11 female respondents and 4 male respondents. While in the control group there were 8 female respondents and 7 male respondents. According to the results of research conducted by Sri Ujii (2015) regarding the relationship between age and gender with cholesterol levels in obese patients at Abdul Moeloek Hospital, Lampung Province, the results showed that there was no significant relationship between gender and cholesterol levels, but 
women had a greater risk of developing obesity increase in cholesterol levels. Before menopause women tend to have lower cholesterol levels, but will increase after menopause due to reduced activity of the hormone estrogen after menopause ${ }^{[10]}$.

According to the results of research by Sugiarti (2011) which states that more women are affected by hypercholesterolemia as much as $69 \%$ while men are $31 \%$. This is understandable because most women have activities that are less energy-consuming than men, besides that it is also supported by local culture such as eastern culture which still distinguishes the type of work between women and men [11].

The results of the independent $t$ test showed that the significance value before in the treatment group and control group was 0.063 ( $\mathrm{p}$ value $>0.05$ ) and the significance value after in the treatment group and control group was 0.038 ( $\mathrm{p}$ value $<0.05$ ). The comparison between the treatment group and the control group was intended to determine which treatment group had the most influence in reducing cholesterol levels in the elderly with hypercholesterolemia. The results showed that in the treatment group given coriander extract there was a difference in the average decrease in cholesterol levels.

Coriander contains high amounts of essential oils. This plant is a potential source of lipids because it is rich in petroselinic acid and volatile oil (high in linalool) isolated from the seeds. The results of phytochemical screening of coriander seed extract showed the presence of alkaloid compounds, saponins, tannins, flavonoids, phenolics, triterpenoids, and glycosides ${ }^{[4]}$.

In line with the research results of Rosmiati, et al (2020), coriander seed extract can reduce cholesterol levels in male Swiss' Webster mice, this is supported by the presence of chemical content in coriander, one of which is flavonoid compounds that can reduce cholesterol levels with the mechanism of action of inhibiting 3Hydroxy-3-Methyl-Glutaryl-CoenzymeA
(HMG-CoA) reduction which causes a decrease in cholesterol synthesis ${ }^{[12]}$.

In addition, cholesterol can be reduced due to several things, namely, a diet high in cholesterol and fat, the excretion of cholesterol into the colon through bile acids is too little and the production of endogenous cholesterol in the liver associated with genetic factors is too much. Control efforts made in reducing total cholesterol levels are by following a low-fat diet or using non-pharmacological treatment, namely by consuming coriander seed extract ${ }^{[13]}$.

\section{CONCLUSION}

Based on the results of the study above, it shows that there is a significant effect of coriander seed extract on cholesterol reduction in the elderly with hypercholesterolemia with $\mathrm{p}$-value before 0.063 and $p$-value after 0.038 . For further researchers, it is recommended to conduct research by adding several variables such as congenital disease factors and other factors that can affect the decrease in blood cholesterol levels.

\section{GRATITUDE}

We would like to thank the Ministry of Education, Culture, Research and Technology for providing a research grant for the 2020 funding year. We would also like to thank PSPJ (Center for Herbal Medicine and Services) of Pekalongan City for collaborating in the manufacture of coriander seed extract as well as all respondents who have assisted in this research.

\section{BIBLIOGRAPHY \\ 1. Djojodibroto D. Respirologi (Respiratory Medicine). Jakarta: EGC. 2012}

2. Dewi, S.R. Buku Ajar Keperawatan Gerontik. Yogyakarta: Deepublis. 2014

3. Kemenkes RI. Survei Kesehatan Dasar Indonesia. Jakarta: Kementrian Kesehatan Republik Indonesia, 2012. 
4. Hasanah N, Dori RS. Daya Hambat Ekstrak Biji Ketumbar (Coriandrum sativum L.) terhadap Pertumbuhan Bakteri Shigella dysenteriae Metode Cakram. Edu Masda Journal. 2019;3(2):115-122.).

5. Hasanah N, Dori RS. Daya Hambat Ekstrak Biji Ketumbar (Coriandrum sativum L.) terhadap Pertumbuhan Bakteri Shigella dysenteriae Metode Cakram. Edu Masda J. 2019;3(2):115122.).

6. Wagiran. Metodologi Penelitian Pendidikan: Teori dan Implementasi. Yogyakarta: Deepublish. 2014

7. Suherwin. Hubungan Usia, Jenis Kelamin Dan Riwayat Penyakit Dengan Kejadian Penyakit Jantung Koroner Di Instalasi Gawat Darurat Rumah Sakit Tk.II Dr. Ak. Gani Palembang Tahun 2016. Jurnal Aisyiyah Medika. Volume 1, Nomor 1, Februari 2018

8. Zuhroiyyah, Siti., Sukandar, Hadyana., Sunaryo Barki S. Hubungan Aktivitas Fisik dengan Kadar Kolesterol Total, Kolesterol Low- Density Lipoprotein pada Masyarakat Jatinangor. Fakultas Kedokteran Universitas Padjadjaran. 2017

9. Mintalangi, Milsa. Perbandingan Kadar Kolesterol Total pada Masyarakat Semi Kota dan Desa di Kabupaten Minahasa Selatan, Fakultas Kesehatan Masyarakat. Universotas Sam Ratulangi Manado (Disertasi). 2013

10. Ujiani, Sri . Hubungan usia dan jenis kelamin dengan kadar kolesterol penderita obesitas RSUD Abdul Moeloek Provinsi Lampung. Jurnal Kesehatan, Volume VI, Nomor 1, April 2015, hlm 43-48
11. Lilis, Sugiarti. Latifah. Hubungan obesitas, umur dan jenis kelamin terhadap kadar kolesterol darah. Jurnal Sains Natural Universitas Nusa Bangsa, Vol 1, No. 1, Januari 2011, hlm 73-80

12. Rosmiati, Karolin. Aritonang. Kajian Fitokimia dan Aktifitas Antihiperkolesterolemia Ekstrak Ketumbar (Coriandrum Sativum) pada Mencit Swiss Webster. Media Farmasi Poltekkes Makasar. Vol XVI No 2, Oktober 2020

13. Sutanto. Cekal (Cegah \& Tangkal) Penyakit Modern Hipertensi, Stroke, Jantung, Kolesterol dan Diabetes. Yogyakarta: ANDI. 2010 